Institute of Animal Breeding Science', University of Bonn, Germany, Institute of Anatomy, Physiology and Hygiene of Fam Animals², University of Bonn, Germany, Institute of Animal Sciences', Humboldt University of Berlin, Germany

KLAUS WIMMERS', CORNELIA LIPPERHEIDE'², SIRILUCK PONSUKSILI' FRIEDRICH SCHMOLL', TORSTEN HARDGE ${ }^{3}$, BRIGITTE PETERSEN $^{2}$ and KARL SCHELLANDER'

\title{
Haemolytic complement activity and C3c serum concentration in pigs
}

Dedicated to Prof. Dr. Dr. h.c. Gottfried Leuthold on the occasion of his $65^{\text {th }}$ birthday

\begin{abstract}
Summary
Because of the importance of the complement system in disease resistance through direct lysis of target cells and support of other mechanisms of the immune system, individual variation in haemolytic complement activity and $\mathrm{C} 3$ concentration in pigs prior and after vaccination were evaluated. Possible effects on the variation of these parameters were investigated. Total complement activity was determined based on complement-mediated haemolysis of antibody-sensitised erythrocytes and C3c levels were measured by immunonephelometry in German Landrace pigs and an experimental pig population. Both methods revealed remarkable individual differences. The arithmetic means of total haemolytic complement activity including all pigs were $42.3 \pm 28.2$ $\mathrm{U} / \mathrm{ml}$ before vaccination and $59.1 \pm 50.6 \mathrm{U} / \mathrm{ml}$ after three immunisations. Mean plasma concentrations of $\mathrm{C} 3 \mathrm{c}$ were between $.102 \pm .035 \mathrm{~g} / \mathrm{l}$ before immunisation and $.126 \pm .038 \mathrm{~g} / \mathrm{l}$ on day 4 after Aujeszky vaccination. Existing phenotypic variation may be in part influenced by pig genetic factors. Both haemolytic complement activity as well as $\mathrm{C} 3 \mathrm{c}$ serum levels are potentially useful measures of complement capacity on the way to improve defence power against many pathogens by breeding.
\end{abstract}

Key words: complement activity, $\mathrm{C} 3 \mathrm{c}$ level, disease resistance, pig, immunonephelometry, acute phase proteins

\section{Zusammmenfassung}

Titel der Arbeit: Hämolytische Komplementaktivität und C3c Serumkonzentration bei Schweinen

Mit Blick auf die Bedeutung des Komplementsystems für Krankheitsresistenz durch die Fähigkeit zur direkten Lyse von Fremdzellen und die Unterstützung von Mechanismen des Immunsystems wurden die individuelle Variation in der hämolytischen Komplementaktivität und die C3c-Konzentration bei Schweinen vor und nach Impfungen untersucht. Mögliche Einflüsse auf diese Variation wurden betrachtet. Bei Tieren der Deutschen Landrasse und einer Versuchspopulation wurde die Komplementaktivität basierend auf der Hämolyse sensibilisierter Erythrozyten und die C3c Konzentration immunonephelometrisch erfaßt. Hohe individuelle Variation wurde mit beiden $\mathrm{Meßmethoden} \mathrm{beobachtet.} \mathrm{Die} \mathrm{durchschnittliche} \mathrm{hämolytische} \mathrm{Komplementaktivität}$ aller Tiere betrug vor den Impfungen $42,3 \pm 28,2 \mathrm{U} / \mathrm{ml}$ und $59,1 \pm 50,6 \mathrm{U} / \mathrm{ml}$ nach drei Impfungen. Die durchschnittliche Plasmakonzentration an $\mathrm{C} 3 \mathrm{c}$ betrug $0,102 \pm 0,035 \mathrm{~g} / 1$ vor den Impfungen und $0,126 \pm 0,038$ g/l am Tag 4 nach der Aujeszky-Impfung. Die bestehende phänotypische Variation hat vermutlich teilweise genetische Ursachen. Sowohl die hämolytische Komplementaktivität als auch die C3c Serumkonzentration sind potentiell nützliche Maßstäbe für die Kapazität des Komplementsystems wenn es darum geht züchterisch die Abwehrkraft gegen eine Vielzahl von Pathogenen zu erhöhen.

Schlüsselwörter: Komplementaktivität, C3c-Konzentration, Krankheitsresistenz, Schwein, Immunonephelometrie, Akute-Phase-Proteine 


\section{Introduction}

There are several physiological mechanisms which influence disease resistance. The innate immune system represents a primary defence line and act earlier than the adaptive immune system. Furthermore the innate, non specific immunity is active against numerous pathogens. The protein cascade of the complement system is an important component of the innate, non-specific immunological defence. The system is capable of direct killing and lysis of microorganisms in the absence of specific antibodies. The complement proteins mediate phagocytosis and control inflammation. But the complement system interacts also with antibodies in humoral immune response and with T-cells (ROITT et al., 1996). Furthermore the complement system is involved in hyperacute xenograft rejection of different species combination (WANG et al., 1992). The complement system consists of more than 30 proteins most of which act as a catalyst for the next.

The most important component is $\mathrm{C} 3$ which is the key enzyme in both ways of activation of the complement system: (1) the classical pathway is mainly activated by immune complexes and (2) the alternative pathway is activated by the presence of "protected surfaces" after spontaneous hydrolysis of C3. C3 is constitutively synthesised in hepatozytes. The synthesis is increased after different noxes (VOLANAKIS, 1995). In this sense C3 acts as a acute phase protein. Acute phase proteins are hepatic proteins whose plasma concentration increase following tissue injury and inflammation. Collectively, acute phase proteins perform serveral important functions, including recognition and elimination of pathogenic microorganisms, prevention of damage to host tissues by inflammatory proteolytic enzymes and oxygen metabolites, and restoration of tissues integrity. Acute phase proteins are sensitive indicators of illness even of subclinical diseases and of immunological stress. In pig haptoglobin is one of the most important acute phase proteins (FRANCISCO et al., 1996; HALL et al., 1992; EURELL et al., 1990).

The present study was designed in order to evaluate the individual differences in complement activity and $\mathrm{C} 3$ concentration in pigs prior and after vaccination and to evaluate possible effects on the variation of these parameters. Therefore total complement activity was determined based on complement-mediated haemolysis of antibody-sensitised erythrocytes. The concentration of C3c, a stable soluble fragment cleaved from $\mathrm{C} 3 \mathrm{~b}$ during complement activation, was measured by immunonephelometry. Haptoglobin concentration was measured in order to judge of the state of health of the animals.

\section{Material and Methods}

Source of animals and vaccinations

F2-piglets $(n=203)$ of a resource population based on the reciprocal cross of Berlin Miniature Pigs and Durocs as well as purebred German Landrace piglets $(n=39)$ were kept under uniform management conditions at our research farms to limit environmental variables that might affect complement activity values and plasma 
concentration of acute phase proteins. The piglets were vaccinated with a Mycoplasma vaccine at and age of 7 weeks, with an Aujeszky vaccine at an age of 14 weeks and with a PRRS vaccine at an age of 16 weeks. Blood samples were taken from each piglet immediately prior to immunisation (day 0 ) and on day 4 and day 10 after vaccination with the exception that after PRRS vaccination blood was only taken once at day 10. Blood was cooled immediately and sera and plasma were harvested within 2 hours and stored at $-70^{\circ} \mathrm{C}$ until analysis. A pool of sera of several pigs was used as a reference serum.

\section{Haemolytic complement system assay}

The haemolytic activity of the classical pathway of the complement system was determined by a method modified from LIU and YOUNG (1988). In contrast to other methodes described (BARTA and BARTA, 1982; CLARK and TSCHIDA, 1985) it is based on the measurement of the change in light-scattering properties of erythrocytes upon lysis rather than on the hemoglobin concentration after lysis. The test conditions were evaluated and standardised for the assay of pig complement (WIMMERS et al., 1998). Sheep red blood cells (SRBC) were sensitised with haemolysin (Sigma) as described by the manufacturer. The optimal SRBC-sensitising concentration was determined by serial dilutions of haemolysin. The highest dilution of haemolysin giving maximal lysis with the highest dilution of pooled serum was found to be 1:150. For future testing haemolysin was diluted 1:75 in veronal buffer. Sensitised SRBCs were used as a $2 \%$ cell-suspension. Serial dilutions of test sera $(50 \mu l)$ in veronal buffer $(50 \mu \mathrm{l})$ were made in replicates of 2 in flat-bottomed 96 -well microtitre plates. To each serum dilution $50 \mu \mathrm{l}$ of sensitised SRBCs were added and the plates were incubated for $90 \mathrm{~min}$ at $37^{\circ} \mathrm{C}$. The results were read at $650 \mathrm{~nm}$ in a microplate reader (ThermoMax, Molecular Devices). The readings were transformed according to the method of VON KROGH (1916) and the haemolytic titre was expressed as the titre that lysed $50 \%$ of the erythrocytes (CH50 U/ml).

\section{Determination of $\mathrm{C} 3 \mathrm{c}$ and $\mathrm{Hp}$ concentration}

The serum concentration of $\mathrm{C} 3 \mathrm{c}$ was measured immunonephelometrically. The Behring-Nephelometer-System and anti-human-C3c-antiserum (Dade Behring GmbH, Marburg) were used. This human antiserum showed a significant cross reaction to porcine $\mathrm{C} 3 \mathrm{c}$ fragments as demonstrated by Ouchterlony test (data not shown). A reference curve was established using a human standard solution (Dade Behring $\mathrm{GmbH}$, Marburg). Immunonephelometric measurement is based on the measurement of light-scattering due to formation of immune complexes. Results are given as concentration of $\mathrm{C} 3 \mathrm{c}(\mathrm{g} / \mathrm{l})$. Simultatiously the concentration of haptoglobin $(\mathrm{Hp})$ was also measured immunonephelometrically using anti-human-Hp-antiserum according to LIPPERHEIDE et al. (1998).

\section{Statistical analysis}

Data were analysed using the following models: 


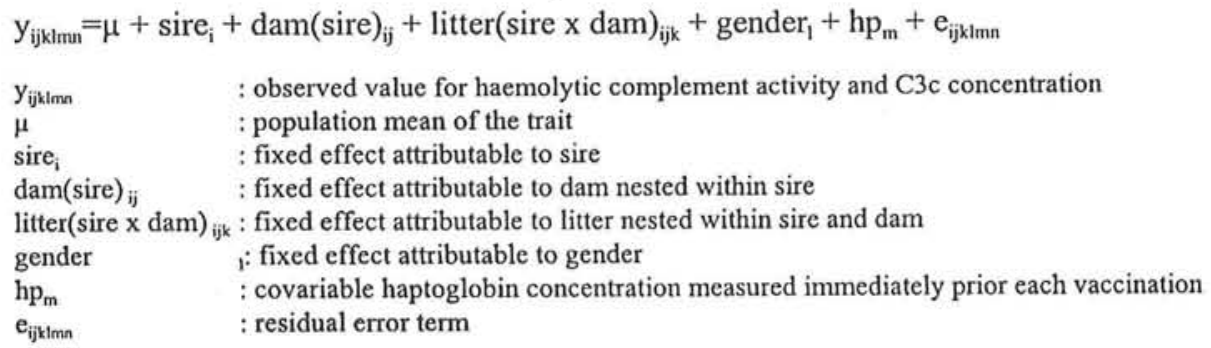

Estimation was performed with the general linear model procedure of SAS (SAS for Windows Release 6.12). The repeated statement was used in order to consider that the dependent variables represent repeated measurements of the same animal.

In order to evaluate the trend of the measurements after the vaccinations the following mixed model was used:

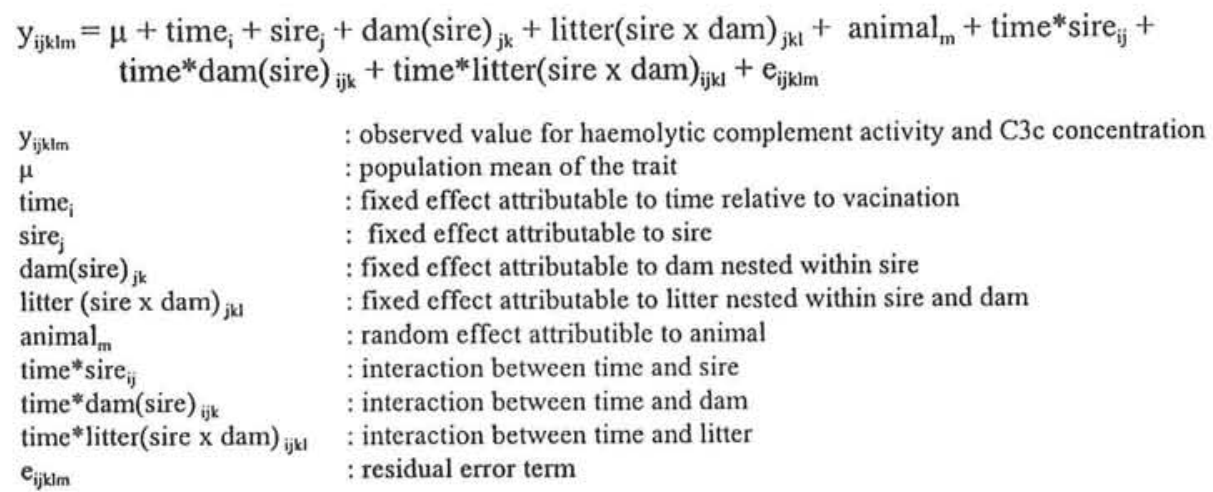

\section{Results}

The arithmetic means of total haemolytic complement activity including all pigs were lowest before any treatment with $42.3 \pm 28.2 \mathrm{U} / \mathrm{ml}$ and were highest after all three immunisations with $59.1 \pm 50.6 \mathrm{U} / \mathrm{ml}$. Mean plasma concentrations of $\mathrm{C} 3 \mathrm{c}$ were between $.102 \pm .035 \mathrm{~g} / \mathrm{l}$ before immunisation and $.126 \pm .038 \mathrm{~g} / 1$ on day 4 after Aujeszky vaccination (Table 1). As indicated by the high standard deviations there was remarkable individual variation in complement activity and to a lower amount in $\mathrm{C} 3 \mathrm{c}$ concentration. Haemolytic complement activity was elevated to day 4 and 10 after Mycoplasma vaccination. After Aujeszky immunisation activity increased to day 4 but slightly decreased from day 4 to day 10 . Complement activity of day 10 after PRRS vaccination was higher than before. $\mathrm{C} 3 \mathrm{c}$ concentration showed a short-termed increase after vaccinations. The same was seen for $\mathrm{Hp}$ concentration. Correlations between haemolytic complement activity measured prior and after immunisations and corresponding $\mathrm{C} 3 \mathrm{c}$ levels was not significant and close to zero (-.071 to .061). Correlations of complement activity to $\mathrm{Hp}$ was also not signifcant and ranged between .008 and .327. C3c levels and corresponding Hp levels were significantly correlated (.204 to .594$)$. 
Table 1

Arithmetic means and standard deviations of haemolytic complement activity, $\mathrm{CH} 50, \mathrm{C} 3 \mathrm{c}$ and haptoglobin, $\mathrm{Hp}$, levels prior $(1,4,7)$ and after immunisation with Mycoplasma $(2,3)$, Aujeszky $(5,6)$ and PRRS $(8)$ vaccines (Arithmetische Mittelwerte und Standardabweichungen der hämolytischen Komplementaktivität,CH50, der C3c und Haptoglobin, Hp, Konzentration vor $(1,4,7)$ und nach Immunisierung mit Mycoplasma (2, 3), Aujeszky $(5,6)$ und PRRS $(8)$ Vakzinen)

\begin{tabular}{|c|c|c|c|c|c|c|c|c|}
\hline & $\begin{array}{l}\text { Vacci- } \\
\text { nation }\end{array}$ & $\begin{array}{c}\text { CH50 } \\
{[\mathrm{U} / \mathrm{ml}]} \\
\text { meantstd }\end{array}$ & & $\begin{array}{l}\text { Vacci- } \\
\text { nation }\end{array}$ & $\begin{array}{c}\mathrm{C} 3 \mathrm{c} \\
{[\mathrm{g} / \mathrm{l}]} \\
\text { meantstd }\end{array}$ & & $\begin{array}{l}\text { Vacci- } \\
\text { nation }\end{array}$ & $\begin{array}{c}\mathrm{Hp} \\
{[\mathrm{g} / \mathrm{l}]} \\
\text { meantstd }\end{array}$ \\
\hline $\mathrm{CH}-1$ & Myco & $42.3 \pm 28.2$ & $\mathrm{C} 3 \mathrm{c}-1$ & Myco & $.102 \pm .035$ & $\mathrm{Hp}-1$ & Myco & $.376 \pm .238$ \\
\hline $\mathrm{CH}-2$ & plasma & $48.1 \pm 30.7$ & C $3 c-2$ & plasma & $.118 \pm .040$ & Hp-2 & plasma & $.508 \pm .242$ \\
\hline CH-3 & & $50.9 \pm 36.6$ & $\mathrm{C} 3 \mathrm{c}-3$ & & $.114 \pm .035$ & $\mathrm{Hp}-3$ & & $.336 \pm .225$ \\
\hline $\mathrm{CH}-4$ & & $56.2 \pm 40.9$ & C $3 c-4$ & & $.120 \pm .033$ & Hp-4 & & $.336 \pm .238$ \\
\hline $\mathrm{CH}-5$ & Aujeszky & $58.7 \pm 30.2$ & C $3 c-5$ & Aujeszky & $.126 \pm .038$ & Hp-5 & Aujeszky & $.791 \pm .250$ \\
\hline CH-6 & & $56.6 \pm 44.1$ & C $3 c-6$ & & $.124 \pm .053$ & Hp-6 & & $.572 \pm .270$ \\
\hline $\mathrm{CH}-7$ & PRRS & $57.3 \pm 45.9$ & C3c-7 & PRRS & $.118 \pm .036$ & Hp-7 & PRRS & $.472 \pm .264$ \\
\hline CH-8 & & $59.1 \pm 50.6$ & C $3 c-8$ & & $.122 \pm .034$ & Hp-8 & & $.525 \pm .273$ \\
\hline
\end{tabular}

Analysis of variance for total haemolytic complement activity prior and after the three vaccinations indicated that the combined effects in the model accounted for 65 to $82 \%$ of phenotypic variation in the different traits $\mathrm{CH}-1$ to $\mathrm{CH}-8$ (Table 2). The effect of sire, of dam nested within sire and of litter nested within dam and sire contributed significantly to the variation observed in complement activity at each time of blood sampling. Gender did not affect the traits. Haptoglobin concentration measured immediately prior to Aujeszky vaccination significantly affected complement activity prior and 4 days after vaccination. Haptoglobin concentrations measured immediately before the other treatments did not affect the complement activity at corresponding times of measurement. Repeated measures analysis of variance revealed significant between-subject effects of sire, dam nested within sire and litter nested within sire and dam for complement activity during Mycoplasma and Aujeszky vaccination haptoglobin concentration before vaccination was additionally significant. For complement activity before and after PRRS vaccination sire, dam nested within sire and litter nested within sire and dam showed significant between-subject effects. Concerning complement activity during Mycoplasma vaccination repeated measures analysis of variance showed a significant within-subject effect of time of blood sampling and of the interactions between time and sire, dam nested within sire as well as litter nested within sire and dam. The other interactions were not significant. For measurements prior and after Aujeszky vaccination the same significant within-subject effects were found. Only the interaction between time and dam nested within sire was a significant within-subject effect on complement activity before and after PRRS vaccination.

The models used for analysis of variance for $\mathrm{C} 3 \mathrm{c}$ plasma concentration measured during the three vaccination accounted for 37 to $77 \%$ of phenotypic variation in the different traits C3c-1 to C3c-8 (Table 3). The effect of dam nested within sire and litter nested within dam and sire was significant for all measurements. The effect of sire contributed significantly to variation observed in $\mathrm{C} 3 \mathrm{c}-2, \mathrm{C} 3 \mathrm{c}-4, \mathrm{C} 3 \mathrm{c}-5$ and $\mathrm{C} 3 \mathrm{c}-7$. Haptoglobin concentration measured immediately prior to the vaccination significantly 
Table 2

Results of analysis of variance of total haemolytic complement activity obtained prior and after vaccinations (Ergebnisse der Varianzanalyse der hämolytischen Komplementaktivität vor und nach Vakzinationen)

\begin{tabular}{|c|c|c|c|c|c|c|c|c|c|}
\hline & & $\begin{array}{l}\text { time of } \\
\text { bloodtaking }\end{array}$ & $\mathrm{R}^{2}$ & Model & sire & dam & gender & litter & hp \\
\hline $\mathrm{CH}-1$ & Myco- & day 0 & .68 & \#*4 & * & *** & ns & \$* & ns \\
\hline $\mathrm{CH}-2$ & plasma- & day 4 & .73 & $\# * *$ & $* * *$ & *** & ns & $* * *$ & ns \\
\hline $\mathrm{CH}-3$ & vaccine & day 10 & .69 & $* * *$ & $* * *$ & *** & ns & $* * *$ & ns \\
\hline CH-Myk & \multicolumn{2}{|c|}{ between-subject-effects } & & & $* * *$ & $* * *$ & ns & $* * *$ & ns \\
\hline $\mathrm{CH}-4$ & Aujeszky & day 0 & .82 & $* * *$ & 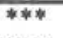 & *** & ns & *** & $* 4$ \\
\hline $\mathrm{CH}-5$ & vaccine & day 4 & .65 & $* *$ & $* * *$ & $* * *$ & ns & $\leftarrow * *$ & 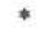 \\
\hline $\mathrm{CH}-6$ & & day 10 & .79 & $* * *$ & $* * *$ & $* * *$ & ns & $* * *$ & ns \\
\hline CH-AK & \multicolumn{2}{|c|}{ between-subject-effects } & & & $* * *$ & **** & ns & $* * *$ & $* * *$ \\
\hline $\mathrm{CH}-7$ & PRRS & day 0 & .72 & *** & 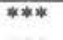 & *市* & ns & $* * *$ & ns \\
\hline $\mathrm{CH}-8$ & vaccine & day 10 & .81 & $* * *$ & $* * *$ & $* * *$ & ns & $* * *$ & ns \\
\hline CH-PRRS & \multicolumn{2}{|c|}{ between-subject-effects } & & & $* * *$ & $* * *$ & ns & $* * *$ & ns \\
\hline
\end{tabular}

affected $\mathrm{C} 3 \mathrm{c}$ concentration at the same time of measurement and at day 10 after PRRS vaccination. Significant between-subject effects for C3c concentration were sire, dam nested within sire and litter nested within sire and dam and haptoglobin concentration at all three vaccinations. Significant within-subject effects on $\mathrm{C} 3 \mathrm{c}$ concentration prior and after Mycoplasma vaccination as well as prior and after PRRS vaccination were time of blood sampling and its interactions with sire, dam nested within sire as well as litter nested within sire and dam. For measurements prior and after Aujeszky vaccination the same interactions and in addition the interaction between time and haptoglobin concentration had significant within-subject effects.

Table 3

Results of analysis of variance of $\mathrm{C} 3 \mathrm{c}$ levels obtained prior and after vaccinations (Ergebnisse der

Varianzanalyse der C3c Konzentration vor und nach Vakzinationen)

\begin{tabular}{|c|c|c|c|c|c|c|c|c|c|}
\hline & & $\begin{array}{l}\text { time of } \\
\text { bloodtaking }\end{array}$ & $\mathrm{R}^{2}$ & Model & sire & dam & gender & litter & $\mathrm{hp}$ \\
\hline $\mathrm{C} 3 \mathrm{c}-1$ & Myco- & day 0 & .57 & ***** & $\mathrm{ns}$ & *** & ns & $* * *$ & *** \\
\hline $\mathrm{C} 3 \mathrm{c}-2$ & plasma- & day 4 & .69 & $* * *$ & $* * *$ & $* * *$ & ns & $* * *$ & ns \\
\hline $\mathrm{C} 3 \mathrm{c}-3$ & vaccine & day 10 & .57 & *4* & ns & $* * *$ & ns & $* * *$ & ns \\
\hline C3c-Myk & between- & ubject-effects & & & $* * *$ & $* * *$ & ns & $* * *$ & $*$ \\
\hline $\mathrm{C} 3 \mathrm{c}-4$ & Aujeszky & day 0 & .61 & **** & $* *$ & **** & ns & \#*** & \#* \\
\hline$C 3 c-5$ & vaccine & day 4 & .74 & *** & *** & $* * *$ & ns & $* * *$ & ns \\
\hline $\mathrm{C} 3 \mathrm{c}-6$ & & day 10 & .37 & $* * *$ & ns & **** & ns & $* *$ & ns \\
\hline $\mathrm{C} 3 \mathrm{c}-\mathrm{AK}$ & between- & ubject-effects & & & ** & $* * *$ & ns & *** & *** \\
\hline $\mathrm{C} 3 \mathrm{c}-7$ & PRRS & day 0 & .77 & *** & **** & **** & ns & *** & *** \\
\hline C $3 c-8$ & vaccine & day 10 & .63 & $* * *$ & ns & $* * *$ & ns & $* * *$ & $* * *$ \\
\hline C3c-PRRS & between- & subject-effects & & & $* *$ & $* * *$ & ns & $* * *$ & *** \\
\hline
\end{tabular}

The mixed model for analysis of variance of the data entered in the univariate mode explained $81 \%$ of phenotypic variation of haemolytic complement activity and $68 \%$ of variation of $\mathrm{C} 3 \mathrm{c}$ plasma concentration. All independent variables and interactions included showed a significant effect on complement activity. For $\mathrm{C} 3 \mathrm{c}$ concentration all effects and interactions were significant with the exception of the effect of dam which was very close to significance $(p=0.057)$. The contrast statement revealed significant difference between complement activity prior Mycoplasma vaccination and after this 
treatment. Differences between complement activity prior and after the viral vaccinations were not significant. Serum concentration before Mycoplasma and Aujeszky immunisation, respectively, were significant lower than on day 4 after the vaccinations. Whereas the difference of $\mathrm{C} 3 \mathrm{c}$ concentration between day 0 and day 10 of Mycoplasma vaccination was significant the corresponding values of Aujeszky treatment were not. Prior (day 0) and after (day 10) PRRS vaccination no significant difference was observed.

\section{Discussion}

Breeding for improved immune defence in farm animals is of interest for three main reasons: (1) Higher disease resistance can improve economical results in farming by decreasing costs of medical treatment and losses. (2) The introduction of animals with improved disease resistance can result in higher product (meat) quality. The danger of transmission of infectious agents or traces of chemotherapeutics is reduced. (3) The health status of animals is an important matter of animal wellfare.

Because of the importance of the complement system in host resistance through direct lysis of target cell and support of other mechanisms of the innate and adaptive immune system haemolytic complement activity was studied. Since C3 is the key protein within the complement cascade special focus was put on its plasma concentration. Studies on complement activity especially on $\mathrm{C} 3 \mathrm{c}$ levels in pigs are quite rare. Mean values of complement activity shown in this study are comparable with values found by other authors (MALLARD et al., 1989; KOMATSU et al., 1998). These authors also found high standard deviations demonstrating high individual variation in haemolytic complement activity.

The influence of genes of the major histocompatibility complex (MHC) on haemolytic complement activity was examined in commercial pigs and Miniature swine (VAIMAN et al., 1978; MALLARD et al., 1989). Significant differences between swine leukocyte antigen (SLA) haplotypes were found in commercial pigs. In Miniature pigs no significant effects of the SLA haplotypes on complement activity were found but least-square mean comparisons revealed differences between the haplotypes indicating an advantage for cc haplotypes. It was suggested that maternal genes outside the MHC have a greater influence on haemolytic complement values than SLA haplotypes (MALLARD et al., 1989). MALLARD et al. (1989) found mean values between $41.32 \pm 20.49$ prior to immunisations in 8 weeks old piglets and 59.93 \pm 54.35 after immunisations with an age of 12 weeks. A non-immunised control group had a complement activity of $40.07 \pm 16.35$ which was not significant different from activity before vaccination. This indicates that there is no elevation of complement activity due to aging but that immunisation leads to activation of the complement system. In Meishan pigs KOMATSU et al. (1998) observed a mean complement activity value of 36.5 before and a significantly increased value of 55.5 after immunisation with bovine serum albumine.

Here we observed an increase of haemolytic complement activity after each vaccination. Complement activity was significantly elevated after Mycoplasma 
vaccination. Increase of complement activity after Aujeszky vaccination was not significant and short-termed - activity was slightly lower on day 10 after vaccination than on day 4-. After PRRS vaccination an increased activity was given on day 10. But the fact that there was an increase of complement activity even between the second measurement after Mycoplasma vaccination and the measurement prior to Aujeszky vaccination and between Aujeszky and PRRS immunisation show that an effect of ageing cannot be excluded. Future studies will attempt to clarify the effect of age on complement activity in our pig population. For the $\mathrm{C} 3 \mathrm{c}$ level a significant increase was found on day 4 after the Mycoplasma and Aujeszky vaccinations. Levels decreased slightly to day 10 but were still higher - in case of Mycoplasma immunisation significantly higher - than on day 0 prior vaccinations. For the PRRS vaccination a slightly higher concentration was found on day 10 than on day 0 ; no data were available concerning day 4 after PRRS immunisation. The same trends were found for Hp levels a well established acute phase protein in pigs.

Results of the analysis of variance showed that of the factors included in the model sire, dam and litter were the most important ones. Our results indicated that besides environmental effects genetic influences are important for variation of complement activity. The fact that the effect of dam and litter were significant indicated that genetic and environmental maternal effects may contribute to phenotypic variation. Variation in complement activity is highest at an age of 16 weeks at the end of the experiment. This supported that genetic influences may be of higher importance than environmental maternal effects.

MALLARD et al. (1989) found no significant effect of sire on complement activity and concluded that heritability is negligible in Miniature pigs. In our analysis of variance it was shown that complement activity at all times of measurement is significantly affected by the sire which supports the existence of genetic influences. In cattle heritability estimates ranged from $.78 \pm .16$ prior and $.68 \pm .15$ after immunisation (LIE et al., 1983). These contradictions may be due to species (pig vs cattle) and/or population (Miniature pig vs Duroc x Berlin-Miniature Pig and German Landrace, respectively) differences or differences in the experimental design. For C3c levels the effect of sire was not significant at all times of measurement.

In the second model calculated in order to consider the trend to complement acitivity and $\mathrm{C} 3 \mathrm{c}$ concentration during the experiment all interactions between time of measurement and sire, dam and litter were highly significant. That means that the trend of complement activity strongly depends on the effects that may be inherited. The same is true for the $\mathrm{C} 3 \mathrm{c}$ levels. These results were confirmed by the results of the repeated statement of the first statistical model used here.

In summary, remarkable high individual variation of haemolytic complement activity and serum $\mathrm{C} 3 \mathrm{c}$ concentration was found. Analysis of variance showed that of the factors included in the model, sire, dam and litter, were the major ones indicating strong genetic influences. Existing phenotypic variation and genetic influence on complement activity may be suitable to breed for high complement capacity in order to improve defence power against many pathogens. Further studies are necessary in order 
to evaluate whether high complement capacity is related to superior immune responsiveness and disease resistance, since recent results give no clear pictures about these interrelations. Furthermore it has to be clarified whether total haemolytic complement activity or serum concentrations of complement components should be considered. Correlations between haemolytic activities and $\mathrm{C} 3 \mathrm{c}$ concentrations were inconsistent. This may be due to the fact that the in vitro potential of the complement system is measured with the first method but the immunonephelometric measurement of $\mathrm{C} 3 \mathrm{c}$ reveals the amount of $\mathrm{C} 3$ cleaved due to in-vivo complement activation. Level of $\mathrm{C} 3 \mathrm{c}$ showed trends which paralleled the development of $\mathrm{Hp}$ concentration prior and after vaccinations. Correlation between $\mathrm{C} 3 \mathrm{c}$ and $\mathrm{Hp}$ levels were moderate but significant. In this terms $\mathrm{C} 3 \mathrm{c}$ is a acute phase protein showing the typical curve with an early reaction on any kind of injury, inflammation or infection. Therefore both haemolytic complement activity as well as C3c serum levels are potentially useful measures of defence power.

\section{References}

BARTA, O,; BARTA, V.:

Testing of haemolytic complement and ist components. Manual of veterinary clinical immunology. 2nd ed. Baton Rouge, La: Louisiana State University Press, (1982)

CLARK, J.C.; TSCHIDA, A.R.:

Improved assay for total haemolytic complement. J. Clin. Lab. Immunol. 18 (1985), 191-194

EURELL, T. E.; EURELL, J. C.; BANE, D. P.; HALL, W. F.:

Serum haptoglobin is associated with experimentally-induced atrophic rhinitis in swine. Proc. Int. Pig Vet. Soc. $11^{\text {th }}$ congress, Lausanne, Switzerland, (1990), 65

FRANCISCO, C. J.; SHRYOCK, T. R.; BANE, D. P.; UNVERZAGT, L.:

Serum haptoglobin concentration in growing swine after intranasal challenge with Bordetella bronchiseptica and toxigenic Pasteurella multocida type D. Can. J. Vet. Res. 60 (1996), 222-227

HALL, W. F.; EURELL, T. E.; HANSEN, R. D.; HERR, L. G.:

Serum haptoglobin concentration in swine naturally or experimentally infected with Actinobacillus pleuropneumoniae. J. Am. Vet. Med.Ass. 201 (1992), 1730-1733

KOMATSU, M.; YOSHIWARA, S.; AKITA, T.:

Immunological characteristics of the meishan pig: serum complement activity, serum C3 level, immune response and skin structure. Proceedings of the $6^{\text {th }}$ world congress on genetics applied to livestock production. Armidale, NSW, Australia January 11-16, 27 (1998), 323-326

LIPPERHEIDE, C.; DIEPERS, N.; LAMPREAVE, F.; ALAVA, M.; PETERSEN, B.:

Nephelometric determination of haptoglobin plasma concentrations in fattening pigs. J. Vet. Med. A45 (1998), 543-550

LIE, O.; SYED, M.; SOLBU, H.:

The genetic influence on serum haemolytic complement levels in cattle. Anim. Blood Groups Biochem. Genet. 14 (1983), 51-57

LIU, C.C.; YOUNG, J.D.E.:

A semiautomated microassay for complement activity. J. Immuno Meth. 114 (1988), 33-39

MALLARD, B. A.; WILKIE, B. N.; KENNEDY, B. W.: Influence of major histocompatibility genes on serum haemolytic complement activity in miniature swine. Am. J. Vet. Res. 50 (1989), 359-363

ROITT, I.; BROSTOFF, J.; MALE, D.: Immunology, 4edn. Times mirror international publishers limited, (1996), 13.1-13.17

VAIMAN, M.; HAUPTMANN, G.; MAYER, S.:

Influence of the major histocompatibilty complex in the pig (SLA) on serum haemolytic complement levels. J. Immunogenet. 5 (1978), 59-65 
VOLANAKIS, J.E.:

Transcriptional regulation of complement genes. Annu. Rev. Immunol. (1995), 277-305

VON KROGH, M.:

Colloidal chemistry and immunology. J. Infect. Dis. 19 (1916), 452

WANG, M.W.; JOHNSTON, P.S.; WRIGHT, L.J.; LIM, M.L.; WHITE, D.J.G.:

Immunofluorescent localization of pig complement component 3, regardless of the presence or absence of detectable immunoglobulins, in hyperacutely rejected heart xenografts. Histochem. J. 24 (1992), 102-109

WIMMERS, K.; LIPPERHEIDE, C.; LAMMER, T.; PONSUKSILI, S.; SCHMOLL, F.; PETERSEN, B.; SCHELLANDER, K:

Evaluation of phenotypic variation of complement activity as a parameter of immunocompetency. Proceedings of the 6 th world congress on genetics applied to livestock production. Armidale, NSW, Australia January 11-16, 27 (1998), 265-268

Received: 26.10 .1998

Accepted: 23.11 .1998

Author's addresses

Dr. KLAUS WIMMERS, Dr. SIRILUCK PONSUKSILI, Dr. FRIEDRICH SCHMOLL, Prof. Dr. KARL SCHELLANDER

Rheinische Friedrich-Wilhelms-Universität Bonn

Institut für Tierzuchtwissenschaft

Endenicher Allee 15

D-53115 Bonn

Germany

Dr. CORNELIA LIPPERHEIDE, Prof. Dr. BRIGITTE PETERSEN

Rheinische Friedrich-Wilhelms-Universităt Bonn

Institut für Anatomie, Physiologie und Hygiene der Haustiere

Katzenburgweg 7-9

D-53115 Bonn

Germany

Dr. TORSTEN HARDGE

Humboldt-Universităt zu Berlin

Institut für Nutztierwissenschaften

Invalidenstraße 42

D-10115 Berlin

Germany 